\title{
3 Good tutors are not Dear Enemies in Song Sparrows
}

4 Çağlar Akçay ${ }^{1}$, S. Elizabeth Campbell², Michael D. Beecher ${ }^{2,3}$

5

6 1. Department of Biological Sciences, Virginia Tech, Blacksburg, VA 24061

7 2. Department of Psychology, University of Washington, Seattle, WA 98195

8 3. Department of Biology, University of Washington, Seattle, WA 98195

10 Author for correspondence:

11 Çağlar Akçay

12 Department of Biological Sciences

13 Virginia Tech

14 Blacksburg, VA 24061

15 akcay.caglar@gmail.com

16

17 Keywords: song learning, cooperation, communication, aggression, social learning 


\section{Good tutors are not Dear Enemies in Song Sparrows}

20

21

22

23

24

25

26

27

28

\section{7}

\section{Abstract}

Bird song is the most widely studied example of vocal learning outside human language and shares important parallels with it, including the importance of social factors during development.

Our understanding of how social factors affect song learning however remains surprisingly incomplete. Here we examine the possible role of aggressive interactions in determining song “tutor" choice in song sparrows (Melospiza melodia), a songbird in which individuals display song learning strategies ranging from learning primarily from one tutor, to learning a few songs each from a number of tutors. We test two hypotheses: The Competition hypothesis suggests that young birds learn more from tutors with whom they compete especially intensely and predicts that tutees will respond with high aggression to tutor songs. In contrast the Cooperation hypothesis suggests that song learning reflects a cooperative relationship between the tutor and the tutee and predicts that tutees will respond with low aggression to tutor songs. In a playback experiment we found that birds respond more aggressively to songs of their tutors than they do to songs of strangers and that the strength of aggressive response correlated positively with how much they had learned from that tutor. These results provide the first field evidence for the hypothesis that young males preferentially learn their songs from adult males with whom they compete most intensely during the song-learning phase, and perhaps afterwards. 


\section{Introduction}

40

41

42

43

44

45

Although vocal communication is ubiquitous in the animal kingdom, social learning of vocal signals is limited to a few taxa, including humans (but not other primates), cetaceans, bats, elephants and three orders of birds (Baptista \& Schuchmann, 1990; Boughman, 1998; Marler \& Tamura, 1964; Pepperberg, 1994; Reiss \& McCowan, 1993). Of these, song in songbirds is the best studied system next to human language (Beecher \& Brenowitz, 2005; Catchpole \& Slater, 2008).

Early studies showed striking parallels between the development of vocal signals in humans and songbirds including an early sensitive period, a predisposition to learn conspecific vocalizations, a babbling (or subsong) stage, and the necessity of auditory feedback for normal development (Marler, 1970). Another parallel is the social nature of vocal development. Although the social aspect of vocal development is obvious for humans, the potent role of social interactions in song learning was not fully appreciated until laboratory studies used live birds as song "tutors" rather than recorded song as had been conventional (Baptista \& Petrinovich, 1984, 1986). Although it is now widely accepted that song learning is a social process in which young birds (tutees) hear and engage in interactions with adults (tutors), there is a dearth of studies attempting to identify the critical social factors (Beecher, 2008).

Despite the many striking parallels between human and songbird vocal learning, the key social factors in vocal learning may be quite different for the two taxa. In particular, whereas the tutortutee (teacher-student) relationship in humans is clearly a cooperative one, with both parties typically related, the common case in songbirds is that tutor and tutee are unrelated competitors. This is because most songbirds commence song-learning only after they disperse from their natal 
61 area, and thus their song tutors are future territorial competitors rather than their parents usually

62 fathers (here and throughout the rest of paper we focus on male song and use the male pronoun,

63 but note that female singing is common in other species, particularly in the tropics; Riebel, Hall,

$64 \&$ Langmore, 2005). Species where fathers act as song tutors for their sons are rare (Grant \&

65 Grant, 1996; Greig, Taft, \& Pruett-Jones, 2012; Immelmann, 1969). Instead, in most songbirds

66 song tutors are unrelated adults some of whom will be their territorial competitors come the next

67 breeding season (Beecher \& Brenowitz, 2005; Brenowitz \& Beecher, 2005). This point can be

68 illustrated with song sparrows living in Washington State (Beecher, 2017). In this population,

69 song learning occurs in the period after natal dispersal and before the bird's first breeding season

70 the following spring. Neighbors typically 'share' song types, and this song sharing has been

71 shown to be a result of song learning (Beecher, 2008; Beecher, Campbell, \& Stoddard, 1994;

72 Nordby, Campbell, \& Beecher, 1999). The period of song learning also coincides with territory

73 establishment during which young birds also engage in aggressive interactions with their future

74 neighbors (Arcese, 1989; Nice, 1943), and shared songs are used by adult birds as part of a

75 graded signaling system in aggressive interactions (Akçay, Tom, Campbell, \& Beecher, 2013;

76 Burt, Campbell, \& Beecher, 2001). All of these lines of evidence suggest that song learning may

77 be influenced by the amount of aggressive and competitive interactions between the tutors and

78 the young birds. We term this hypothesis the "Competition" hypothesis.

79 A different line of thinking, however, suggests that even under these circumstances the songbird

80 tutor-tutee relationship could be an at least partially cooperative one. As has been shown for

81 numerous diverse taxa, territorial neighbors often enter into a 'Dear Enemy' relationship where

82 they are more tolerant of their neighbors than they are of strangers (Akçay et al., 2009; Fisher,

83 1954; Temeles, 1994). Hence it is possible that it might actually benefit an established territorial 
84 adult to 'teach' his songs to a young bird who is in a position to become his future neighbor; in

85 short, a ‘dear tutor-tutee' relationship could underlie and support a 'dear enemy' relationship. This idea can be seen as an extension of the observation that that in many group-living species

87 with vocal learning (e.g. dolphins, parrots and cooperatively breeding songbirds), vocal learning seems to have an affiliative function in which individuals learn their vocalizations from members of their social groups (Akçay, Hambury, Arnold, Nevins, \& Dickinson, 2014; Berg, Delgado, Cortopassi, Beissinger, \& Bradbury, 2012; Brown, Farabaugh, \& Veltman, 1988; Price, 1998; with recent reviews of animal 'teaching' in which the putative tutor does not obtain immediate benefits (and may even pay immediate costs) by engaging in the teaching of a tutee (Hoppitt et al., 2008). Under this view, older birds would reap some form of delayed benefit from tutoring young birds and having them as neighbors. This benefit might come in the form of increased breeding success (Beletsky \& Orians, 1989), access to extra-pair females that are mated to the young males or less competition for within-pair paternity from these young males (Hill, Akçay, Campbell, \& Beecher, 2011). The last two potential benefits are based upon the findings that in many songbirds including song sparrows the older males are more likely to successfully pursue extra-pair matings (Akçay et al., 2012; Hill et al., 2011; Hsu, Schroeder, Winney, Burke, \&

$101 \quad$ Nakagawa, 2015).

Here we present a test of competition and cooperation hypotheses in song sparrows. Song sparrows are close-ended learners who learn their songs in the period after dispersal from the natal area and the beginning of their first breeding season the following spring and do not change their song repertoire in subsequent years (Nordby, Campbell, \& Beecher, 2002). Extensive field studies have shown that while on average a bird copies about half of his 8 or 9 songs from a 
107 single tutor (the best tutor) and the rest from multiple other tutors, there is a range of learning

108 strategies, varying from copying all his songs from a single tutor to copying a single song from

109 each of 8 or 9 tutors (Akçay, Campbell, Reed, \& Beecher, 2014; Beecher et al., 1994; Nordby et

110 al., 1999; Nordby, Campbell, \& Beecher, 2007). As noted above, adult song sparrows use shared

111 songs as part of a graded signaling system that may indicate the primary role of competitive

112 interactions in song learning. At the same time, multiple studies have shown that male song

113 sparrows can individually recognize their neighbors and generally show reduced aggression to

114 neighbors compared to strangers (Akçay, Reed, Campbell, Templeton, \& Beecher, 2010; Akçay

115 et al., 2009; Wilson \& Vehrencamp, 2001), suggesting the opportunity for cooperative

116 interactions with potential tutors exists.

117 We tested the two hypotheses by asking whether a bird would be respond more or less

118 aggressively to a simulated intrusion by a former tutor compared to a stranger, and whether

119 aggressive response would vary with how much the young bird had learned from the tutor.

120 Specifically, in a playback experiment to subjects with known song learning histories, we

121 compared their aggressive response to the tutor from whom they had learned the most, to their

122 aggressive response to songs from a stranger. The cooperation hypothesis predicts that tutees

123 should respond less aggressively to their best tutors than to strangers, and less aggressively to

124 tutors from whom they learned more than from tutors from whom they learned less. In contrast,

125 the competition hypothesis predicts precisely the opposite: subjects should respond more

126 aggressively to their best tutors than to strangers, and more aggressively to tutors from whom

127 they learned more than from tutors from whom they learned less. 


\section{Methods}

\section{(a) Study site and subjects}

We studied a banded population of song sparrows in Discovery Park, Seattle, Washington, USA. Between 2009 and 2014 all the territorial males (about 120 males each year) were banded with a US Fish and Wildlife Service metal band and three colored bands. As a part of our long term study on song learning (Beecher, 2008), the complete song repertoire of each male was also recorded with Marantz PMD 660 recorders and Sennheiser ME66/K6 shot-gun microphones.

135 The full repertoire was considered to be recorded after at least 16 song switches (Nordby et al., 1999). Subjects in the playback experiment were 13 banded and recorded male song sparrows in

137 our study population in Discovery Park, Seattle, Washington, USA. We tested each subject twice on different days with a counterbalanced order for two trial types. The experiments were conducted from March 18 to April 14, 2014.

\section{(b) Tracing song learning}

141 We chose males with known ages and song learning histories that held territories in Spring 2014.

142 Three of the subjects hatched in 2009, 6 in 2010 and 7 in 2011. All the subjects were banded

143 either in juvenile plumage (before their first molt) or singing plastic song before their first Spring

144 when the songs crystallize (around March $1^{\text {st }}$ ). We made sonagrams of all the songs in the

145 repertoire of the tutees and potential tutors using Syrinx (www.syrinxpc.com, John Burt, Seattle,

146 WA). We printed out several variations of each song of all the males. The tutors for each tutee

147 were determined as described in detail in our previous studies (Akçay, Campbell, Reed, et al.,

148 2014; Nordby et al., 1999). Three judges visually compared the songs of the tutees and tutors

149 independently and laid out matching songs on a large table. After this step, the three judges 
150 discussed their best match decisions, and arrived at a consensus. If a single adult had the best

151 matching song for a given tutee song, that tutor got a credit of 1 for that song. If more than one

152 adult had equivalently good matches for a given tutee song, then each tutor got credit of 1/N,

153 where $\mathrm{N}$ was the number of tutors with equally good matching songs. Because of the high level

154 of song sharing in our population (Hill, Campbell, Nordby, Burt, \& Beecher, 1999) splitting

155 credit between multiple tutors happens about half the time (Akçay, Campbell, Reed, et al., 2014).

\section{6 (c) Design and stimuli}

157 Subjects were tested with two songs each from 1) the male with the highest tutoring score for

158 that bird (the bird's 'best' tutor) and 2) a stranger male that held a territory at 1 to $2 \mathrm{~km}$ from the

159 territory of the subject. In all cases the best tutor was no longer present in the study area, most

160 likely to due to death as territorial males do not make significant moves (Akçay, Campbell, \&

161 Beecher, 2015; Arcese, 1989). In seven out of 13 cases, the tutor had been a neighbor with the

162 subject. In the remaining six cases, the tutor had not shared an immediate boundary with the

163 subject but was within two territories of the subject's territory. Previous research in other

164 songbirds has shown that males remember and recognize their familiar neighbors even after

165 these disappear (Godard, 1991; McGregor \& Avery, 1986). We therefore expected that subjects

166 would be able to recognize their tutors.

167 We carried out the playbacks at the center of the subjects' territories to have a standardized

168 location for contrasting responses to strangers vs. tutors. Previous studies in song sparrows (and

169 most of the other songbirds studied) have shown no difference in response strength between

170 stranger playback and a randomly chosen familiar bird, usually a neighbor, at the territory center

171 (Stoddard, 1996) We reasoned therefore that getting a difference in response strength to tutors 
172 compared to strangers in either direction would be stronger test of the alternative hypotheses. We

173 note also that since the tutors had disappeared by the time of the playbacks, and some of the best

174 tutors did not share a boundary with the subject to start with, there was no current shared

175 boundary between subjects and best tutors.

176 The stimuli for the best tutors were chosen from the songs they shared with the tutee (i.e. from

177 the songs that the tutee had learned from the tutor). Stranger songs were non-shared with the

178 subject (as stranger songs almost always are). Playback tapes were created in Syrinx so that

179 stimulus songs (a single rendition per song type) would be presented every ten seconds.

\section{(d) Playback procedure}

181 Each subject was tested twice, once with the songs of his best tutor and once with the songs of a

182 stranger on different days not farther apart than 1 week. The order was counterbalanced across

183 subjects. We started each trial by setting up a speaker (iMainGo, Portable Sound Laboratories,

184 Inc) at the center of the subject's territory. The speaker was connected to an iPod with a $20 \mathrm{~m}$

185 cable. The stimuli were played at approximately $80 \mathrm{~dB}$ SPL, measured at $1 \mathrm{~m}$ (Radio Shack 33-

1862055 sound meter), corresponding to normal broadcast song amplitude. Two observers recorded

187 the behavior of the subject (flights, songs, wing waves, distance with every flight) verbally using

188 the same recording equipment as above. Three minutes after the first sighting of the subject, we

189 switched to the second song type and carried on the trial for another three minutes.

\section{0 (e) Response measures and data analyses}

191 From the trial recordings we extracted the following response measures: duration of the trial

192 (from first sighting of the male to the last playback), number of flights, time spent within $5 \mathrm{~m}$ of

193 speaker, closest approach to the speaker. The numbers of flights and songs were converted to 
194 rates per minute to account for unequal duration of observation across trials due to different

195 latencies to respond.

196 We use rate of flights, proportion of trial spent within $5 \mathrm{~m}$ and closest approach distance as our

197 primary variables of aggression. As these variables were highly correlated with each other we

198 used a principal component analysis (PCA, unrotated, correlation matrix) to arrive at a single

199 aggression score (see the correlation matrix in Table 1). Our previous studies with taxidermic

200 mounts indicate that aggression scores calculated from these measures reliably predict attack

201 (Akçay, Campbell, \& Beecher, 2014; Akçay et al., 2013). These three variables also constitute

202 behaviors that are expression of a "behavioral character" (Araya-Ajoy \& Dingemanse, 2014)

203 corresponding to aggressiveness in this species (Akçay et al., 2015). The first component of the

204 PCA explained $73.6 \%$ of the variance and we took these scores as the aggression scores (see

205 Table 1 for coefficients). Higher aggression scores meant higher levels of aggressive response.

206 We then ran a mixed ANOVA on the aggression scores with the condition as a within-subject

207 factor and proportion learned from best tutor as a between subject covariate.

Table 1. Correlation coefficients ( $p$-values) between aggressive behaviors and the loading coefficients on

209 the PCA (rightmost column).

\begin{tabular}{llllr}
\hline & $\begin{array}{l}\text { flights } \\
\text { (per } \\
\text { minute) }\end{array}$ & $\begin{array}{l}\text { proportion of } \\
\text { time within }\end{array}$ & $\begin{array}{l}\text { closest } \\
\text { approach to } \\
\text { speaker }\end{array}$ & $\begin{array}{l}\text { loading } \\
\text { coefficients } \\
\text { for PCA1 }\end{array}$ \\
\hline flights (per minute) & - & $0.55(0.004)$ & $-0.49(0.01)$ & 0.52 \\
\hline proportion of time within $\mathbf{5 m}$ & - & - & $-0.75(<0.0001)$ & 0.61 \\
\hline closest approach to speaker & - & - & - & -0.6 \\
\hline
\end{tabular}




\section{1 (f) Ethical statement}

212 This research was conducted in accordance with the ABS/ASAB Guidelines for the treatment of

213 animals in behavioural research and teaching, and with approval from the University of

214 Washington Institutional Animal Care and Use Committee (IACUC \# 2207-03) and the U.S.

215 Fish and Wildlife Service banding permit (banding permit \# 20220). We did not observe any

216 adverse effect of handling and banding the birds in our long term study as banding time is

217 minimized and birds returned to their territories immediately (within minutes of capture). All

218 subjects were banded at least one year before the experiment and had been holding their

219 territories for at least one year before the experiment.

\section{Results}

221 Repertoire sizes of subjects ranged from 6 to 12 song types with a mean of 9.15. The number of

222 tutors for each tutee ranged from 1 to 7 . On average, the best tutors accounted for $48 \%$ of the

223 songs in the repertoires of the tutees (range: $15 \%$ to $83.3 \%$ ).

224 Subjects responded more strongly to tutor playback than to stranger playback $\left(\mathrm{F}_{1,11}=13.61, \mathrm{p}=\right.$

2250.004 , Figure 1). 12 out of 13 subjects for whom we had both trials responded more aggressively

226 to the tutor than to the stranger. There was no main effect of proportion of the song repertoire

227 learned from the best tutor $\left(\mathrm{F}_{1,11}=0.03, \mathrm{p}=0.88\right)$ but there was a significant interaction between

228 proportion of song repertoire learned from best tutor and condition (i.e. tutor vs. stranger), $\mathrm{F}_{1,11}=$

$2295.93, p=0.03$. The more the tutee had learned from the best tutor, the more aggressive was his

230 response to that bird's song compared to his response to the stranger song (Figure 2). 
bioRxiv preprint doi: https://doi org/10.1101/112516. this version posted April 16, 2017. The copyright holder for this preprint (which was not certified by peer review) is the author/funder, who has granted bioRxiv a license to display the preprint in perpetuity. It is made available under aCC-BY-NC-ND 4.0 International license.

232 Figure 1. Aggression scores in stranger vs. tutor trials for individual subjects.

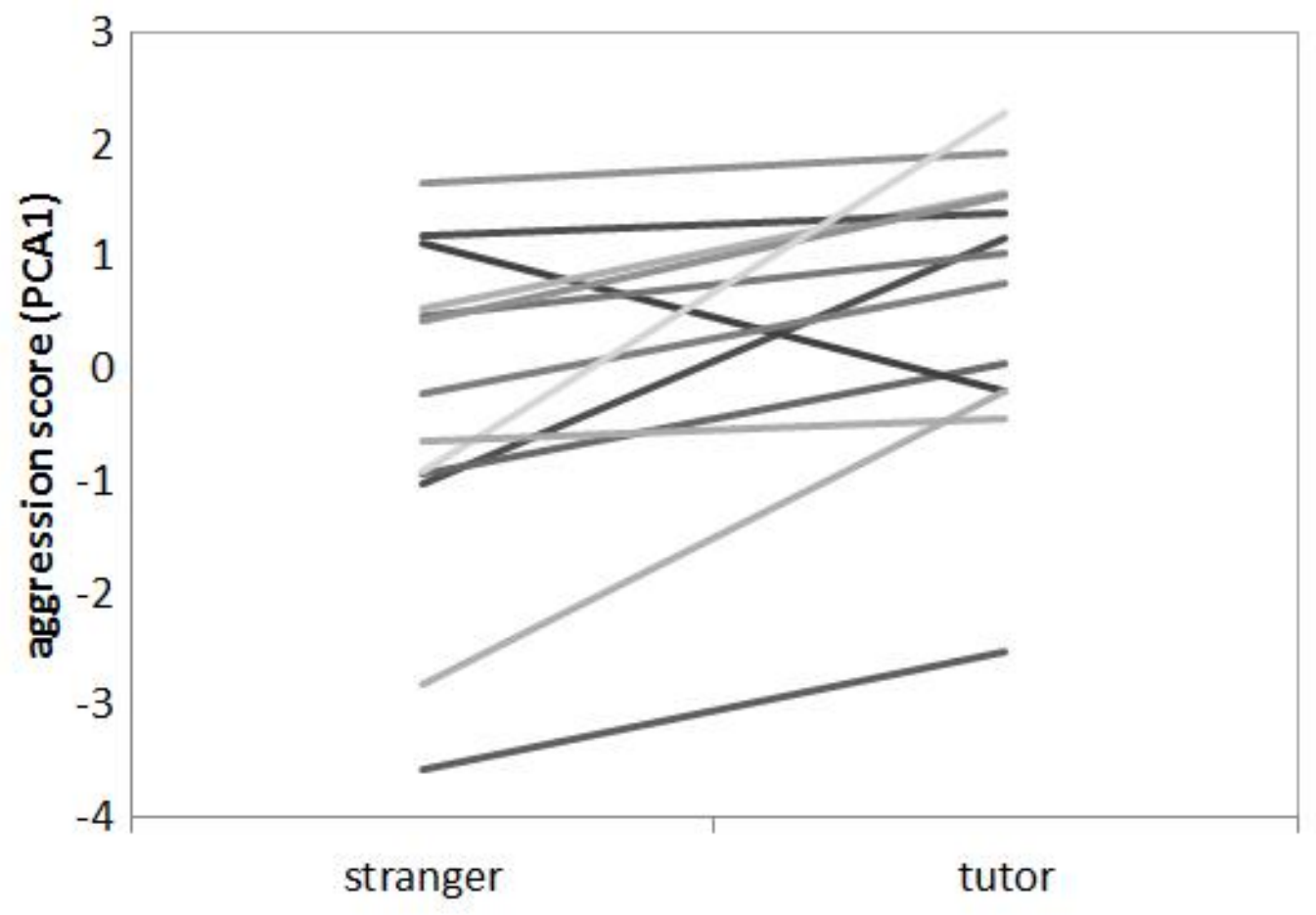


234 Figure 2. The difference in aggression scores between best tutor and stranger trials for individual 235 subjects depending on the proportion of songs they learned from their best tutor.

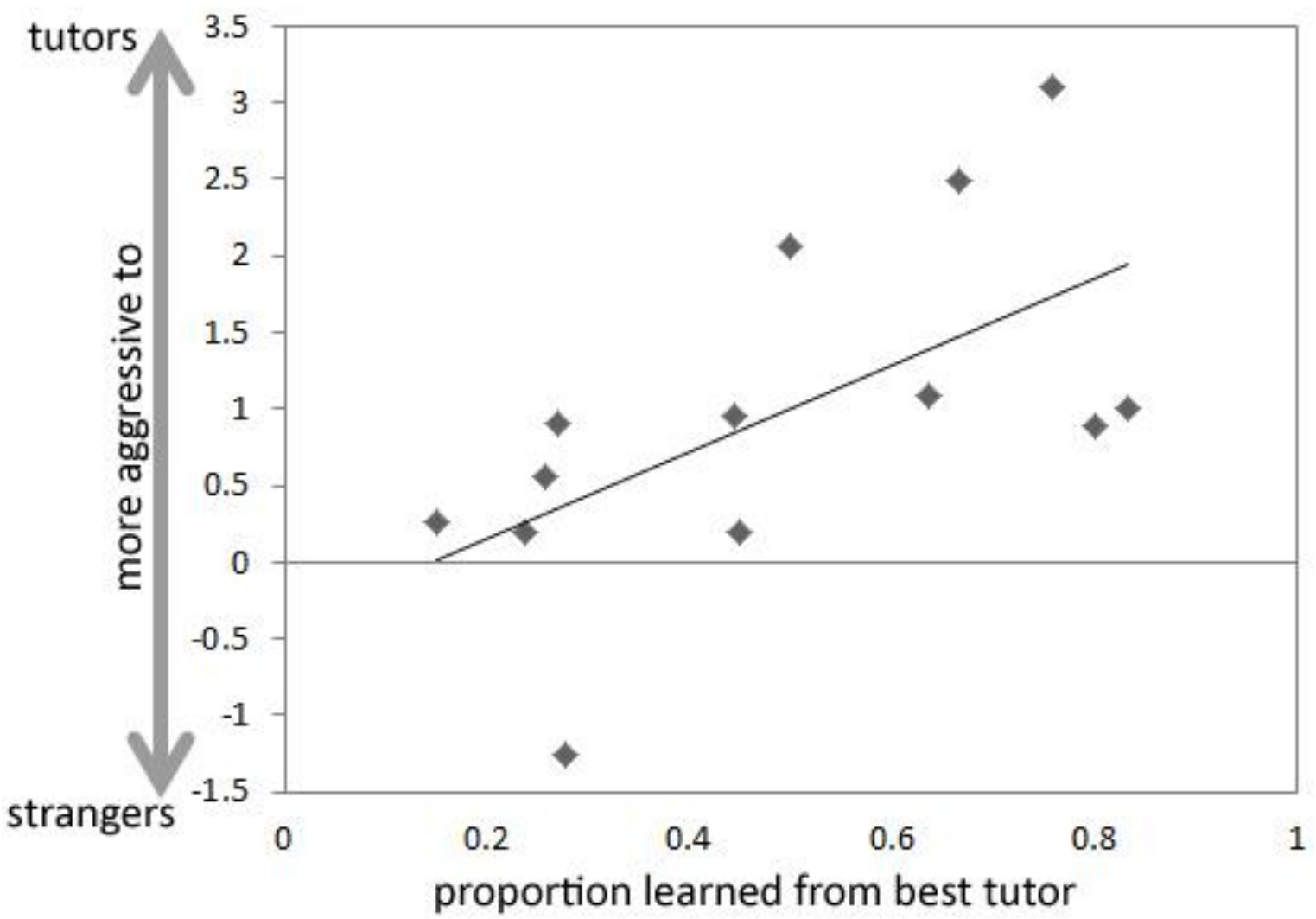

Discussion

238 We observed two effects in this experiment. First, subjects responded more aggressively to

239 simulated intrusions by their former best tutors than to those of strangers. Second, the difference

240 in response strength to tutors vs. stranger was larger the more songs the subject had learned from

241 that tutor. These results support the competition hypothesis which predicted that tutors will elicit

242 a higher response than strangers and that the strength of response will depend on the degree of

243 song learning from that tutor. Below, we first discuss and critically evaluate some alternative

244 explanations before discussing the implications of these results for the role of social interactions

245 during song learning. 
246 Ruling out alternative hypotheses

247 Previous studies by our group and others with song sparrows in both western and eastern

248 populations put the present findings in a fuller context and rule out certain alternative

249 interpretations. One possible interpretation of the first effect is that birds respond more strongly

250 to shared song than to unshared song. However, two previous studies found that song sparrows

251 did not respond more aggressively to own (self) song, which by definition is shared compared to

252 stranger (i.e. non-shared) song (McArthur, 1986; Searcy, McArthur, Peters, \& Marler, 1981). In

253 a more direct test, we also failed to detect differences in responses to shared vs. non-shared

254 stranger songs (Akcay, McKune, Campbell and Beecher, in preparation). These results show that

255 song sparrows do not in general respond more aggressively to shared songs compared to non-

256 shared songs, eliminating this alternative explanation.

257 A second alternative explanation for a stronger response to tutors compared to strangers is that

258 birds respond more strongly to local songs from tutors that used to hold territories close to

259 subjects compared to stranger songs coming from birds that lived farther away. However, such

260 discrimination is typically seen only over much larger distances than those involved in our study:

261 in Searcy and colleagues' study of eastern song sparrows (Searcy, Nowicki, Hughes, \& Peters,

262 2002), discrimination was achieved only for non-local songs from $540 \mathrm{~km}$ away.

263 A final alternative explanation is that the present results may be explained by retaliation to a

264 familiar neighbor (i.e. the tutors in our experiment) who broke off the Dear Enemy relationship.

265 In our previous research we did indeed show that song sparrows increase aggression towards

266 defecting neighbors intruding on neighbor territories (Akçay et al., 2010; Akçay et al., 2009).

267 This retaliation however, cannot explain the present results as even a retaliation strategy does not 
268 predict a higher response to a defecting neighbor than stranger. Indeed, there have been at least

269 five different studies by five different research groups examining responses of male song

270 sparrows neighbors vs. strangers inside the territory of a focal bird (Harris \& Lemon, 1976;

271 Kroodsma, 1976; Moser-Purdy, MacDougall-Shackleton, \& Mennill, 2017; Searcy et al., 1981;

272 Stoddard, Beecher, Horning, \& Campbell, 1991). As summarized in Table 3, the relative

273 response strength to neighbors vs. strangers varies depending on the location, with the

274 differences between neighbor and stranger conditions being most pronounced at the boundary

275 with the neighbor being tested, and getting weaker or disappearing altogether at the territory

276 center. In none of the studies however, did neighbor (or familiar) song elicit a higher response

277 than stranger song at the territory center (see also Falls \& Brooks, 1975; Stoddard, 1996). For

278 instance, in the study most comparable to the present one, Stoddard and colleagues (1991)

279 showed that while song sparrows are less aggressive to their neighbors when these are simulated

280 singing at the appropriate territory boundary compared to strangers (the quintessential Dear

281 Enemy effect), they responded equally aggressively to neighbors and strangers when the

282 playbacks were carried out at the center of the territory (as in the present experiment) or at an

283 inappropriate boundary (Stoddard et al., 1991; see also Stoddard, Beecher, Horning, \& Willis,

284 1990). Overall, the conclusion from these studies suggest that song sparrows (and other

285 songbirds) respond either equally strongly to strangers and neighbors or less strongly to

286 neighbors than to strangers. Therefore, retaliation against a familiar individual cannot explain the

287 present results. 
Table 3. Studies with song sparrows contrasting responses to neighboring and non-neighboring (stranger) males' song inside the territory boundaries. In each of the five previous studies stranger

291 playbacks elicited either higher or equal responses compared to neighbor playbacks.

\begin{tabular}{|c|c|c|c|}
\hline study & location & Stranger distance & Result \\
\hline $\begin{array}{l}\text { Harris \& } \\
\text { Lemon (1976) }\end{array}$ & $\begin{array}{l}\text { "within the territory of the } \\
\text { bird being tested, towards the } \\
\text { boundary of his neighbour." }\end{array}$ & $\begin{array}{l}\text { "separated by } 2 \text { to } 6 \text { other } \\
\text { territories" }\end{array}$ & $\begin{array}{l}\text { No significant difference in } \\
\text { response strength to } \\
\text { neighbors and strangers* }\end{array}$ \\
\hline $\begin{array}{l}\text { Kroodsma } \\
\text { (1976) }\end{array}$ & $\begin{array}{l}\text { "several meters... inside the } \\
\text { territorial boundary" }\end{array}$ & $\begin{array}{l}\text { "between } 100-200 \mathrm{~m} \text { but } \\
\text { never more than } 800 \mathrm{~m} \text { from } \\
\text { the experimental male" }\end{array}$ & $\begin{array}{l}\text { Stronger response to } \\
\text { strangers than neighbors }\end{array}$ \\
\hline $\begin{array}{l}\text { Searcy et al. } \\
\text { (1981) }\end{array}$ & $\begin{array}{l}\text { "near the boundary with the } \\
\text { neighbor whose song was to } \\
\text { be used" }\end{array}$ & $\begin{array}{l}\text { "a territory } 0.2 \text { to } 1.0 \mathrm{~km} \\
\text { distant from the subject's } \\
\text { territory" }\end{array}$ & $\begin{array}{l}\text { No significant difference in } \\
\text { response strength to } \\
\text { strangers vs. neighbors }\end{array}$ \\
\hline $\begin{array}{l}\text { Stoddard et al. } \\
\text { (1991) }\end{array}$ & $\begin{array}{l}\text { "approximate geometric } \\
\text { territory center" } \\
\text { "opposite boundary" }\end{array}$ & "at least 0.5 km distant" & $\begin{array}{l}\text { No significant difference in } \\
\text { response strength to } \\
\text { strangers vs. neighbors } \\
\text { No significant difference in } \\
\text { response strength to } \\
\text { strangers vs. neighbors }\end{array}$ \\
\hline $\begin{array}{l}\text { Moser-Purdy et } \\
\text { al. (2017) }\end{array}$ & $\begin{array}{l}\text { "10 m inside the subject's } \\
\text { territory, nearest to the } \\
\text { boundary with the neighbor" }\end{array}$ & "at least 2 km away" & $\begin{array}{l}\text { stronger response to } \\
\text { strangers compared } \\
\text { neighbors, except equal } \\
\text { response during the fertile } \\
\text { period of the subject's mate }\end{array}$ \\
\hline Present study & Territory center & $\begin{array}{l}\text { 1- } 2 \mathrm{~km} \text { from the territory of } \\
\text { the subject }\end{array}$ & $\begin{array}{l}\text { Stronger response to best } \\
\text { tutors compared to } \\
\text { strangers }\end{array}$ \\
\hline
\end{tabular}
tutor song than stranger song, with this difference being larger the more they had learned from the tutor, suggests that neighbors regarded the intrusion by the tutor-neighbor as a higher threat

297 than even that by a stranger. We interpret these results as implying that the relationship between 298 a tutor and tutee is not in a cooperative relationship. Instead, the increased aggression towards 
that birds recognize their former best tutors and that their learning history is reflected in their aggressive response to these tutors.

Note that there is a third hypothesis that might be confused with the Competition hypothesis but is in fact distinct from it. We call it simply the Aggression hypothesis, which states that the young birds learn the most songs from birds that are most aggressive in general. In some cases, it is further assumed that birds who are more aggressive are superior in quality to those birds who are less aggressive. We have done two previous studies that found no support for this hypothesis. In the first study (Akçay, Campbell, \& Beecher, 2014; Akçay, Campbell, Reed, et al., 2014) we measured aggressiveness in adult birds in our study population and found it highly repeatable but unable to explain any of the variance in the 'tutoring success' of these birds in one year: young song sparrows did not learn more songs from tutors who were generally more aggressive. In the second study (Akçay et al., 2015), we compared the survival rates of birds who varied in aggressiveness and found that on average more aggressive birds do not survive longer on territory than do less aggressive birds. To be clear, the Competition hypothesis refers to a background of aggressive interactions between a specific tutor and a specific tutee, while the Aggression hypothesis refers specifically to the general effects on song tutoring of the consistent individual differences in aggressiveness (across time and across contexts) of between tutors.

\section{Implications for the function of song learning}

One interpretation of the finding that the aggressive response to tutors co-varied positively with the amount of learning from that tutor is that young males learn more from tutors with whom they engage in more aggressive interactions. This can be considered an adaptive learning strategy given what we know about the function of song in aggressive interactions in song sparrows. 
322 Extensive field studies in our population have revealed that shared songs with neighbors are used

323 in a graded and hierarchical signaling system (Beecher, Campbell, Burt, Hill, \& Nordby, 2000;

324 Burt et al., 2001; Searcy, Akçay, Nowicki, \& Beecher, 2014). In particular, shared songs are

325 used in two ways: as a 'song type match' to a neighbor singing the same song type (Beecher et

326 al., 2000) and as a 'repertoire match' to a neighbor singing a different but still shared song type

327 (Beecher, Stoddard, Campbell, \& Horning, 1996). These signals indicate different levels of

328 aggressive intention, with type matching being a reliable signal indicating willingness to escalate

329 and eventually attack (Akçay et al., 2013; Burt et al., 2001) and repertoire matching being an

330 intermediate signal indicating attention to the opponent's singing but not a direct escalation.

331 Non-shared songs are used to indicate unwillingness to continue the interaction (Beecher \&

332 Campbell, 2005). These graded signals are used in a hierarchical way such that type matching is

333 followed by higher level threat signals such as soft songs and wing waves, and eventually

334 physical attack if the opponent does not back down, as he could by switching to a different song

type (Akçay et al., 2013; Burt et al., 2001).

Given these functions of shared songs in aggressive interaction, it is likely adaptive for young song and potentially avoid getting into physical aggression that could be costly to both parties.

340 On the flip-side, if birds interact with multiple neighbors aggressively throughout song learning,

341 the birds may try to overlap their song repertoire with multiple tutors by learning one or two

342 songs from each.

343 A significant caveat to the present results is that they only indirectly support for the Competition 
345 song learning. Ideally, we would want to observe the direct aggressive interactions between the

346 tutors and tutees during the period of song learning, although previous attempts by our group

347 using extensive radio-tracking failed to yield significant amounts of aggressive interactions

348 between young birds and potential tutors (Templeton, Reed, Campbell, \& Beecher, 2012).

349 Nevertheless, detailed field studies have shown that new birds often do engage in repeated

350 aggressive interactions with territory owners in order to carve out their own territory (Arcese,

351 1989; Nice, 1943). It is possible that intense aggressive interactions mostly happen in a limited

352 time frame when the young bird first establishes his territory, which in our population can

353 happen any time between their first Summer (as early as July and August) and the following

354 Spring (as late as May). More detailed studies are needed, particularly ones that would take

355 advantage of automated tracking systems that can monitor tutors and tutees around the clock for

356 extended periods of time (e.g. Rutz et al., 2012). Such automated systems could be used to detect

357 when territories are first established and to quantify how many interactions the young birds have

358 with their neighbors during this period. Until then, the present results provide only tentative

359 support of the competition hypothesis. 


\section{References}

Akçay, Ç., Campbell, S. E., \& Beecher, M. D. (2014). Individual differences affect honest signaling in a songbird. Proceedings of the Royal Society of London, Series B: Biological Sciences, 281, 20132496.

Akçay, Ç., Campbell, S. E., \& Beecher, M. D. (2015). The fitness consequences of honesty: under-signalers have a survival advantage in song sparrows. Evolution, 69, 3186-3193.

Akçay, Ç., Campbell, S. E., Reed, V. A., \& Beecher, M. D. (2014). Song sparrows do not learn more songs from aggressive tutors. Animal Behaviour, 94, 151-159.

Akçay, Ç., Hambury, K. L., Arnold, J. A., Nevins, A. M., \& Dickinson, J. L. (2014). Song sharing with neighbours and relatives in a cooperatively breeding songbird. Animal Behaviour, 92, 55-62.

Akçay, Ç., Reed, V. A., Campbell, S. E., Templeton, C. N., \& Beecher, M. D. (2010). Indirect reciprocity: song sparrows distrust aggressive neighbors based on eavesdropping. Animal Behaviour, 80, 1041- 1047.

Akçay, Ç., Searcy, W. A., Campbell, S. E., Reed, V. A., Templeton, C. N., Hardwick, K. M., \& Beecher, M. D. (2012). Who initiates extra-pair mating in song sparrows? Behavioral Ecology, 23, 44-50. doi: doi:10.1093/beheco/arr147

Akçay, Ç., Tom, M. E., Campbell, S. E., \& Beecher, M. D. (2013). Song type matching is an honest early threat signal in a hierarchical animal communication system. Proceedings of the Royal Society of London, Series B: Biological Sciences, 280, 20122517. doi: http://dx.doi.org/10.1098/rspb.2012.2517

Akçay, Ç., Wood, W. E., Searcy, W. A., Templeton, C. N., Campbell, S. E., \& Beecher, M. D. (2009). Good neighbour, bad neighbour: song sparrows retaliate against aggressive rivals. Animal Behaviour, 78(1), 97-102. 
Araya-Ajoy, Y. G., \& Dingemanse, N. J. (2014). Characterizing behavioural 'characters': an evolutionary framework. Proceedings of the Royal Society of London, Series B: Biological Sciences, 281(1776), 20132645.

Arcese, P. (1989). Territory acquisition and loss in male song sparrows. Animal Behaviour, 37(Part 1), 45-55.

Baptista, L. F., \& Petrinovich, L. (1984). Social interaction, sensitive phases and the song template hypothesis in the white-crowned sparrow. Animal Behavior, 32, 172-181.

Baptista, L. F., \& Petrinovich, L. (1986). Song development in the white-crowned sparrow: Social factors and sex differences. Animal Behaviour, 34(5), 1359-1371.

Baptista, L. F., \& Schuchmann, K. L. (1990). Song learning in the Anna hummingbird (Calypte anna). Ethology, 84(1), 15-26.

Beecher, M. D. (2008). Function and mechanisms of song learning in song sparrows. Advances in the study of behavior, 38, 167-225.

Beecher, M. D. (2017). Birdsong learning as a social process. Animal Behaviour. doi: http://dx.doi.org/10.1016/j.anbehav.2016.09.001

Beecher, M. D., \& Brenowitz, E. A. (2005). Functional aspects of song learning in birds. Trends in Ecology \& Evolution, 20, 143-149.

Beecher, M. D., \& Campbell, S. E. (2005). The role of unshared songs in singing interactions between neighbouring song sparrows. Animal Behaviour, 70, 1297-1304.

Beecher, M. D., Campbell, S. E., Burt, J. M., Hill, C. E., \& Nordby, J. C. (2000). Song type matching between neighboring song sparrows. Animal Behavior, 59, 21-27. 
Beecher, M. D., Campbell, S. E., \& Stoddard, P. K. (1994). Correlation of song learning and territory establishment strategies in the song sparrow. Proceedings of the National Academy of Sciences, USA, 91, 1450-1454.

Beecher, M. D., Stoddard, P. K., Campbell, S. E., \& Horning, C. L. (1996). Repertoire matching between neighbouring song sparrows. Animal Behaviour, 51(4), 917-923.

Beletsky, L. D., \& Orians, G. H. (1989). Familiar Neighbors Enhance Breeding Success in Birds. Proceedings of the National Academy of Science, 86 7933-7936.

Berg, K. S., Delgado, S., Cortopassi, K. A., Beissinger, S. R., \& Bradbury, J. W. (2012). Vertical transmission of learned signatures in a wild parrot. Proceedings of the Royal Society BBiological Sciences, 279(1728), 585-591. doi: 10.1098/rspb.2011.0932

Boughman, J. W. (1998). Vocal learning by greater spear-nosed bats. Proceedings of the Royal Society of London. Series B: Biological Sciences, 265(1392), 227-233.

Brenowitz, E. A., \& Beecher, M. D. (2005). Song learning in birds: diversity and plasticity, opportunities and challenges. Trends Neurosci, 28(3), 127-132.

Brown, E. D., Farabaugh, S. M., \& Veltman, C. J. (1988). Song sharing in a group-living songbird, the Australian magpie, Gymnorhina tibicen: Part I. Vocal sharing within and among social groups. Behaviour, 104(1-2), 1-28.

Burt, J. M., Campbell, S. E., \& Beecher, M. D. (2001). Song type matching as threat: a test using interactive playback. Animal Behaviour, 62(1163-1170).

Catchpole, C. K., \& Slater, P. J. B. (2008). Bird song: biological themes and variations. Cambridge, UK: Cambridge University Press.

Falls, J. B., \& Brooks, R. J. (1975). Individual recognition by song in white-throated sparrows. II. Effects of location. Canadian Journal of Zoology, 53(10), 1412-1420. 
430

431

432

433

434

435

436

437

438

439

440

441

442

443

444

445

446

447

448

449

450

451

Fisher, J. B. (1954). Evolution and bird sociality. In J. Huxley, A. C. Hardy \& E. B. Ford (Eds.), Evolution as process (pp. 71-83). London: Allen \& Unwin.

Godard, R. (1991). Long-term memory of individual neighbors in a migratory songbird. Nature, $350(6315), 228-229$.

Grant, B. R., \& Grant, P. R. (1996). Cultural inheritance of song and its role in the evolution of Darwin's finches. Evolution, 50, 2471-2487

Greig, E. I., Taft, B. N., \& Pruett-Jones, S. (2012). Sons learn songs from their social fathers in a cooperatively breeding bird. Proceedings of the Royal Society B: Biological Sciences, 279(1741), 3154-3160.

Harris, M. A., \& Lemon, R. E. (1976). Responses of male song sparrow (Melospiza melodia) to neighbouring and non-neighbouring individuals. Ibis, 118(3), 421-424.

Hill, C. E., Akçay, Ç., Campbell, S. E., \& Beecher, M. D. (2011). Extrapair paternity, song and genetic quality in song sparrows. Behavioral Ecology, 22, 73-81.

Hill, C. E., Campbell, S. E., Nordby, J. C., Burt, J. M., \& Beecher, M. D. (1999). Song sharing in two populations of song sparrows (Melospiza melodia). Behavioral Ecology and Sociobiology, 46, 341-349.

Hoppitt, W. J., Brown, G. R., Kendal, R., Rendell, L., Thornton, A., Webster, M. M., \& Laland, K. N. (2008). Lessons from animal teaching. Trends in Ecology \& Evolution, 23(9), 486493.

Hsu, Y. H., Schroeder, J., Winney, I., Burke, T., \& Nakagawa, S. (2015). Are extra-pair males different from cuckolded males? A case study and a meta-analytic examination. Molecular Ecology, 24(7), 1558-1571. 
452 Immelmann, K. (1969). Song development in the zebra finch and other estrildid finches. In R. A.

453

454

455

456

457

458

459

460

461

462

463

464

465

466

467

468

469

470

471

472

473

474

Hinde (Ed.), Bird vocalizations: their relation to current problems in biology and psychology (pp. 61-74). London: Cambridge Univ. Press.

Kroodsma, D. E. (1976). The effect of large song repertoires on neighbor "recognition" in male song sparrows. Condor, 78, 97-99.

Marler, P. (1970). Birdsong and speech development: could there be parallels? American Scientist, 58, 669-673.

Marler, P., \& Tamura, M. (1964). Culturally transmitted patterns of vocal behavior in sparrows. Science, 146, 1483-1486.

McArthur, P. D. (1986). Similarity of playback songs to self song as a determinant of response strength in song sparrows (Melospiza melodia). Animal Behaviour, 34(1), 199-207.

McGregor, P. K., \& Avery, M. I. (1986). The unsung songs of great tits (Parus major): Learning neighbours' songs for discrimination. Behavioral Ecology and Sociobiology, 18(4), 311316.

Moser-Purdy, C., MacDougall-Shackleton, E. A., \& Mennill, D. J. (2017). Enemies are not always dear: male song sparrows adjust dear enemy effect expression in response to female fertility. Animal Behaviour, 126, 17-22.

Nice, M. M. (1943). Studies in the life history of the song sparrow II. The behavior of the song sparrow and other passerines. Transactions of the Linnean Society of New York, 6, 1-328.

Nordby, J. C., Campbell, S. E., \& Beecher, M. D. (1999). Ecological correlates of song learning in song sparrows. Behavioral Ecology, 10, 287-297.

Nordby, J. C., Campbell, S. E., \& Beecher, M. D. (2002). Adult Song Sparrows do not Alter their Song Repertoires. Ethology, 108(1), 39-50. 
475 Nordby, J. C., Campbell, S. E., \& Beecher, M. D. (2007). Selective attrition and individual song repertoire development in song sparrows. Animal Behavior, 74, 1413-1418.

477 Pepperberg, I. M. (1994). Vocal learning in grey parrots (Psittacus erithacus): effects of social interaction, reference, and context. Auk, 111, 300-313.

479

480

481

482

483

484

485

486

487

488

489

490

491

Price, J. J. (1998). Family-and sex-specific vocal traditions in a cooperatively breeding songbird. Proceedings of the Royal Society of London. Series B: Biological Sciences, 265(1395), 497-502.

Reiss, D., \& McCowan, B. (1993). Spontaneous vocal mimicry and production by bottlenose dolphins (Tursiops truncatus): Evidence for vocal learning. Journal of Comparative Psychology, 107(3), 301.

Riebel, K., Hall, M. L., \& Langmore, N. E. (2005). Female songbirds still struggling to be heard. Trends in Ecology \& Evolution, 20(419-420).

Rutz, C., Burns, Z. T., James, R., Ismar, S. M. H., Burt, J., Otis, B., . . St Clair, J. J. H. (2012). Automated mapping of social networks in wild birds. Current Biology, 22(17), R669R671.

Searcy, W. A., Akçay, Ç., Nowicki, S., \& Beecher, M. D. (2014). Aggressive Signaling in Song Sparrows and Other Songbirds. Advances in the Study of Behavior, 46, 89-125.

Searcy, W. A., McArthur, P. D., Peters, S. S., \& Marler, P. (1981). Response of Male Song and Swamp Sparrows to Neighbour, Stranger, and Self Songs. Behaviour, 77, 152-163.

Searcy, W. A., Nowicki, S., Hughes, M., \& Peters, S. (2002). Geographic song discrimination in relation to dispersal distances in song sparrows. The American Naturalist, 159, 221-230.

Sharp, S. P., McGowan, A., Wood, M. J., \& Hatchwell, B. J. (2005). Learned kin recognition cues in a social bird. Nature, 434(7037), 1127-1130. 
498 Stoddard, P. K. (1996). Vocal recognition of neighbors by territorial passerines. . In D. E.

499

Kroodsma \& D. E. Miller (Eds.), Ecology and evolution of acoustic communication in

500 birds (pp. 356- 374). Ithaca, New York: Cornell University Press.

501 Stoddard, P. K., Beecher, M. D., Horning, C. L., \& Campbell, S. E. (1991). Recognition of

502 individual neighbors by song in the song sparrow, a species with song repertoires. Behavioral Ecology and Sociobiology, 29(3), 211-215.

504 Stoddard, P. K., Beecher, M. D., Horning, C. L., \& Willis, M. S. (1990). Strong neighborstranger discrimination in song sparrows. Condor, 92, 1051-1056.

506 Temeles, E. J. (1994). The role of neighbors in territorial systems: when are they 'dear enemies'? Animal Behavior, 47, 339-350.

508 Templeton, C. N., Reed, V. A., Campbell, S. E., \& Beecher, M. D. (2012). Spatial movements and social networks in juvenile male song sparrows. Behavioral Ecology, 23(1), 141-152.

510 Wilson, P. L., \& Vehrencamp, S. L. (2001). A test of the deceptive mimicry hypothesis in songsharing song sparrows. Animal Behaviour, 62, 1197-1205. 
bioRxiv preprint doi: https://doi.org/10.1101/112516; this version posted April 16, 2017. The copyright holder for this preprint (which was not certified by peer review) is the author/funder, who has granted bioRxiv a license to display the preprint in perpetuity. It is made available under aCC-BY-NC-ND 4.0 International license. 